\title{
The Role of The Headmaster as an Innovator in The Vocational High School Field of Business and Management Padang City
}

\author{
Nellitawati Nellitawati \\ Universitas Negeri Padang \\ ఏ e-mail: nellitawati@gmail.com
}

\begin{abstract}
The goals of this research are to see information about the headmaster's role as an innovator. The population is 127 teachers, and the sample is 83 people that taken by proportional random sampling. The instrument of this research is a question with Likert scale models that tested for validity and reliability. Data analyzed using mean score and performance level. The result from this research are the headmaster's role of an innovator in The Vocational High School Field of Business and Management Padang City stay in good enough category.
\end{abstract}

Keyword: headmaster's, innovator

Copyright (C) 2018 IICET (Indonesia) - All Rights Reserved

Indonesian Institute for Counseling, Education and Therapy (IICET)

\section{INTRODUCTION}

The reform era has brought changes in various lives (Winarno, 2007); (Parawansa, 2002). One of them is a change in the rapid development of technology and information, making everyone or group must make changes and introduce renewals to pursue the efficiency and effectiveness of the achievement of goals in life. In this era of globalization and reform, the challenge for the education world is increasingly complex, starting from the rapid increase of population and the increasing desire after the society to get education, which cumulatively demand the availability of adequate educational facilities. Furthermore, the development of modern science requires a solid foundation of education and high mastery of continuous ability, which requires a longer education in accordance with the concept of life-long education (Sudarsana, 2016).

An important issue discussed since 1999 relating to education is an attempt to implement the SchoolBased Management (SBM) concept in schools so that schools are well managed and can make educational reforms (educational innovations) at all times in order to improve the quality of education ( Umaedi, U., Hadiyanto, H., \& Siswantari, S., 2014; Sutarto, M., Darmansyah, D., \& Warsono, S., 2014). To face these challenges and problems requires a deep rethinking and new, progressive approach. New ideas as a result of rethinking must be able to solve unsolved problems only in a traditional or commercial way. New ideas and approaches that meet these requirements are called innovations in education.

Implementation of educational innovation cannot be separated from an innovator or implementer of innovation itself. Whether a school can innovate in anticipation and proportion to changes, depends on the headmaster (Rahman, 2010). In accordance with the headmaster role as Educator, Manager, Administrator, Supervisor, Leader, Innovator, and Motivator (Mahmood, 1993; Kusuma, 2004; Muriati, 2008; Mulyasa, 2011; Manik, 2011). Furthermore, according to (Suparlan, 2006; in Susanto, 2012) said that there are several roles that must be possessed by the headmaster who is EMASLIMDEF (Educator, Manager, Administrator, 
Supervisor, Leader, Innovator, Motivator, Dynamicator, Evaluator, and Facilitator). The headmaster is an innovator or innovator at school. Schools as educational institutions and headmasters as educational innovators in schools, are responsible for the success of an educational institution as a whole. Headmaster as an innovator will reflect the ways he does his job (Septiana, 2013). Innovators are people who make renewal (Result, 1993, Thamrin, 2015). According to Widianti (2016) someone who always innovates then can be said an innovative, innovators are called an innovator. Furthermore, Komariah et al (2005) innovator is a reformer, pioneer, or the person who most quickly open themselves and accept innovation, even become innovation seekers. Mc Keown in Ancok (2012) states that innovation is a change from something, both incremental (bit by bit) and radical changes. Further according to Suwarno (2008) innovation is an idea, practice, or object that is considered new by the individual. In this case the headmaster to do (renewal) the education system that is considered still monotonic and classical, so that with the innovation is expected to create an atmosphere of quality education and character (Ifdil, I., 2010), which can adapt to the times. As an innovator, the headmaster is also required to be able to develop innovative learning models at school (Maduratna, 2013). Headmaster as the leader of education in school, has an important role in improving the quality of learning process within the school he leads (Triyanto, 2013).

So the headmaster as an innovator must have the right strategy for harmonious relationships with the environment, finding new ideas, implementing new ideas, integrating each activity, setting an example for all school staff, and developing innovative learning models (Barnes T.1998; Bass 1995, Mukhtar \& Iskandar 2009), and the headmaster also needs to increase self-disclosure (Ifdil, I., 2013). According to Gaustad (in Ekosiswoyo, 2016) Headmasters have a key role in managing schools, and modeling students and teachers. Furthermore, Rahardja (2004) suggests a smooth communication between teachers, and headmasters can improve teacher performance in school, furthermore also so as not to increase teacher work stress (Sandra, R., \& Ifdil, I., 2015).

In general, the implementation of the role of the headmaster in Vocational High School Field of Business and Management Padang City is going well. However, when viewed from the role of the headmaster as an innovator in school is still relatively low. Like the headmaster is less than the maximum in the teacher review Nellitawati, N. (2012). The problem now is the lack of the role of the headmaster as an innovator, especially in Vocational High School Field of Business and Management Padang City. Viewed from the aspect of school management, few renewals or changes that can be done by the headmaster as an innovator of education. This is revealed from the interview that the author did in July 2015 with some teachers at Vocational High School Field of Business and Management Padang City. Based on the results from the interviews revealed some phenomena that occur related to the lack of the role headmaster as an innovator in Vocational High School Field of Business and Management Padang City, such as: (1) Headmaster is not creating good relationship in school environment, it is seen from still teachers are less happy with the behavior of headmasters and other teachers, as well as differences in the treatment of the headmasters of teachers with one teacher, (2) the headmaster is new develop new develop development, ideas development, school development, this is judged by the lack of breakthroughs and ideas in the form of school programs that can improve the quality of education and programs that are run still previous programs, (3) new has new implemented new ideas / programs designed by schools and government well. This can be seen from the many weaknesses and shortcomings of the implementation of new programs implemented by the school, (4) The headmaster has not integrated the planned program of schools with activities carried out school well. As the implementation of learning and student activities that are not in accordance with the vision and mission of the school and the goals of national education, (5) The headmaster does not provide exemplary to all school personnel. This is evident to the headmaster who is still late coming to school and goes out without notice to the authorized staff at the school, (6) The headmaster lacks the development of innovative learning models with the teacher. This is judged by the rarity of headmasters providing guidance and direct instructional assistance to teachers in schools.

This phenomenon occurs because the headmaster still ignores the problems in interpersonal relationships, the headmaster is still implementing existing old programs, limited human resources and the facilities and infrastructure available for the implementation of new ideas in schools. Integration of school programs has not been considered important because the purpose of the school is still focused on the things that are common, the lack of leadership of the headmaster so as not to be an exemplary example for every citizen in the school, the difficulty of the headmaster changes the habits of teaching senior teachers who are 
still doing conventional learning, and it is difficult to provide guidance on more innovative and effective new learning models accordingly with the development of the environment.

\section{METHOD}

This research is a descriptive research. The populations in this study are all teachers of Vocational High School Field of Business and Management Padang City as many as 127 people. Sampling in this research using Simple Random Sampling technique so that got result of sampling counted 83 teachers. The type of data from this study is quantitative data. Technique of data analysis of research result using average formula and level of achievement of classification.

\section{RESULT AND DISCUSSION}

The results from this study will describe the description of data on the role of the headmaster as an innovator includes; (1) establishing a harmonious relationship with the environment, (2) finding new ideas, (3) implementing new ideas, (4) integrating all school activities, (5) giving examples, and (6) developing innovative learning models.

Results of data processing seen from the recapitulation of the role of the headmaster in terms of harmonious relationship with the environment as a whole where the highest score obtained on the aspect of respecting ethical values with an average score of 3.61. Next delegate tasks with an average score of 3.58. And in the aspect of working with teachers and communicating with teachers has the same value with an average score of 3.55. While the lowest average score is on the aspect of motivating teachers with an average score of 3.1. Overall, the average score of the headmaster's role as an innovator in terms of a harmonious relationship with the environment has been accomplished fairly well (3.57).

Furthermore, the results of data processing seen from the recapitulation of the role as the headmaster an innovator in terms of finding new ideas overall where the highest score obtained on the aspect of respecting ethical values with an average score of 3.61. Next delegate tasks with an average score of 3.58. And in the aspect see the pattern of the existing program with an average score of 3.87 . Next on the aspect of accepting all new ideas with an average score of 3.7, followed by leaving the old pattern with an average score of 3.7 and combining new patterns with an average of 3.6. While the lowest average score is in the aspect of sorting out old programs to find new ideas with an average score of 3.1. Overall score of the headmaster's role as an innovator in terms of finding new ideas have been done well (3.6).

Then the results of data processing seen from the recapitulation of the role of the headmaster as an innovator in terms of implementing new ideas overall where the highest score obtained on the aspect of applying some new ideas with an average score of 3.76. Furthermore, coaching the implementation of new ideas with an average score of 3.72. For aspects of continuing and maintaining the implementation of new ideas with an average score of 3.69. And the aspect of rewarding the success of applying new ideas with an average score of 3.56. While the lowest average score on the aspect of support the implementation of new ideas with an average score of 3.1. Overall, the average score of the headmaster's role as an innovator in terms of implementing new ideas has been done well (3.62).

Furthermore the results of data processing seen from the recapitulation of the role of the headmaster as an innovator in terms of implementing new ideas overall where the highest score obtained on the aspect of applying some new ideas with an average score of 3.76. Furthermore, coaching the implementation of new ideas with an average score of 3.72. For aspects of continuing and maintaining the implementation of new ideas with an average score of 3.69. And the aspect of rewarding the success of applying new ideas with an average score of 3.56. While the lowest average score on the aspect of support the implementation of new ideas with an average score of 3.1. Overall, the average score of the headmaster's role as an innovator in terms of implementing new ideas has been done well (3.62). 
School overall where the highest score was obtained on the aspects of assisting in integrating learning activities with an average score of 3.62. The next aspect of integrating the program effectively, efficiently and productively with an average score of 3.60. And in the aspect of work ensures program implementation and goal success with an average score of 3.54. While the lowest average score is in the aspect of the preparation of the program plan with an average score of 3.52. Overall, the average score of the headmaster's role as an innovator in terms of integrating all school activities has been done fairly well (3.57).

Furthermore, the results of data processing seen from the recapitulation of the role of the headmaster as an innovator in terms of providing exemplary overall where the highest score obtained on the aspect of providing exemplary attitudes and behavior with an average score of 3.72. And the aspect gives exemplary about discipline and dress well with an average score of 3.65. While the lowest average score is on the aspect of giving exemplary leadership as a leader with an average score of 3.35. Overall the average score of the headmaster's role as an innovator in terms of giving exemplary has been done quite well (3.57).

Then the results of data processing seen from the recapitulation of the role as the headmaster an innovator in terms of developing innovative learning models overall where the highest score obtained on the aspect of developing professionalism of teachers with an average score of 3.77. Next design the learning materials in the classroom with an average score of 3.60. Aspects involve teachers in developing innovative learning models with an average score of 3.59. Aspects provide opportunities for teachers in learning with an average score of 3.55. Aspect's direct teachers on the use of technology-based media with an average score of 3.34. And on the aspect of working to assist teachers in the application of innovative learning models with an average score of 3.52. While the lowest average score is on the aspect of adjusting learning activities in the environment with an average score of 3.19. Overall, the average score of the headmaster's role as an innovator in terms of developing innovative learning models has been accomplished fairly well (3.57).

Overall, the average score obtained has shown that the headmaster has performed his role as an innovator well enough in Vocational High School Field of Business and Management Padang City. From the results from this study can be concluded that the role of Headmaster as an Innovator in Vocational High School Field of Business and Management Padang City Division performed quite well (3.57).

Based on the results of data analysis that has been the author pointed out, can be seen the role of the headmaster an innovator, there are still aspects that have not been optimal, the lack of the role of the headmaster as an innovator in terms of harmonious relationship to the environment in public vocational schools into the field of business and management of Padang city, in particular, in the aspects of working with teachers, communicating with teachers, motivating teachers and delegating due to the possibility that headmasters rarely interact and less concerned with the problems faced by teachers and less attention to the climate of cooperation among fellow teachers, resulting in cooperation has not been implemented properly. In addition, the headmaster is less skilled and skilled in communicating. This may be due to the lack of experience of the headmaster and still adapt to the surrounding teacher environment.

In terms of motivating the possibility of the headmaster is fewer understandings about the importance of motivation for the implementation of teacher duties. And prefer the good performance in accordance with his wishes, and the headmaster still distinguishes teachers who will be given the task with more trust to teachers who delegate tasks often, for fear if the work delegated less able to delegate to teachers who rarely given the trust.

In relation to the analysis that the authors pointed out above, Wahjosumidjo (2005) explains that in harmonious relationships, the headmaster must be able to position themselves appropriately in groups, able to create satisfaction in subordinates / teachers, to be wise, wise, just and absent, which is harmonized with the working group, the ability to take heart through hospitality, respect the ethical values, equal distribution of duties and responsibilities, kind of, fair, respect and other in this case is the teacher. So with that the 
headmaster can improve his role, so that his role as an innovator as a headmaster can be implemented better than ever.

Furthermore, the role of the headmaster as an innovator in terms of finding new ideas in vocational areas of business and management of Padang City is also less optimal on the old pattern aspect to find new ideas. Furthermore, the headmaster is less proactive to ask the teacher about the programs that have been implemented and what the constraints faced by teachers. So it can be concluded that the weakness of the headmaster relationship with the teacher makes the headmaster lack of information for the development of subsequent programs, and has an impact of the achievement of educational goals in schools.

The not optimal role of the headmaster as an innovator in implementing new ideas in the State Vocational School of Business and Management of Padang City on the aspect of rewarding the success with the idea, may be caused by the headmaster's lack of appraisal of the positive side of the implementation of ideas and wants the idea / programs that are more in line with his wishes. Furthermore, financing constraints and infrastructures become the main problem so the headmaster does not provide support for the implementation of new ideas. So it can be analyzed less the headmaster role of the headmaster as an innovator in two aspects, because the headmaster expects a better program than implemented and lack of funds, supporting facilities and infrastructure that makes fewer innovative programs get support.

The not optimal role of the headmaster as an innovator in terms of integrating all school activities in Vocational High School State Business and Management Padang City, especially on aspects of preparation of plans involved in decision making. It is likely that only authorized parties such as vice headmasters of the respective fields are appointed to draw up a program plan. While teachers as policy implementers are less involved in the planning. Furthermore, the headmaster has not been able to ensure the implementation of the program is likely due to lack of support from relevant stakeholders such as the agency in assisting the program's implementation. So the headmaster is hesitant to determine the decision because of the limitations of school fees in implementing a program. So from the results from the analysis put forward by the headmaster role of the author has not been optimal because it has not involved teachers for the preparation of program plans and lack of support from stakeholders related to the decision taken headmasters.

The not optimal role of the headmaster as an innovator in terms of giving exemplary in Vocational High School State Business and Management Padang City on the aspect of giving exemplary leadership, because the headmaster has not had enough experience in leading the school, this is possible because the current headmaster served newly appointed and frequent headmaster exchanges allow the new headmaster to adapt to his new environment. So it can be analyzed the optimal role of the headmaster as an innovator in aspect gives exemplary as a leader, because the headmaster still has to adapt to its environment.

The not optimal role of the headmaster as an innovator in terms of developing innovative learning model in Vocational High School Field of Business and Management Padang City on the five aspects, probably because the headmaster often intervenes in teacher learning methods that low student values. Furthermore, the headmaster does not involve teachers on the development of innovative learning models, perhaps because the headmaster has not understood the latest learning models, so there has not been much input to the teacher about the learning process in the classroom.

Further limitation of the headmaster in the use of technology-based media is also the reason why the headmaster has not directed many teachers in its use for learning activities and headmasters who are still less concerned about teachers who use the old learning theories resulted in fewer learning activities in accordance with the environment. So it can be analyzed the optimal role of headmasters as innovators in terms of developing innovative learning models, because headmasters have not fully mastered the latest learning models and tend to let teachers use old learning models and are less suited to environmental changes.

\section{CONCLUSION}


Based on the results of research that has been stated in the previous chapter, regarding the role of the headmaster as an innovator in Vocational High School Field of Business and Management Padang City can be concluded that the role of the headmaster as an innovator in terms of good relations with the environment is in the category quite well with the average score- average 3.57. Subsequent headmasters in terms of finding new ideas are in good category with an average score of 3.6 .

Then the role of the headmaster in terms of implementing new ideas in the good category with an average score of 3.62. The next roll of the headmaster in terms of integrating all school activities is in a fairly good category with an average score of 3.57. The role of the headmaster in terms of giving exemplary to the category is quite good with an average score of 3.57. And for the role of the headmaster in terms of developing innovative learning model in the category is quite good with an average score of 3.57.

In general, it can be concluded that the role of the headmaster as an innovator in public vocational school in the field of business and management can be categorized quite well (3.57). To it is necessary for the headmaster to be able to maintain and enhance his role as an innovator in order to get results better.

\section{REFERENCES}

Ancok, Djamaludin. (2012). Psikologi Kepemimpinan dan Inovasi. Jakarta: Erlangga.

Barnes. T (1995) Kaizen Strategies for Successfull Leadership. Alih Bahasa oleh : Widjokongko, Martin (1998) Strategi kaizen untuk Kepemimpinan Sukses. Batam . Interaksasa

Ekosiswoyo, R. (2016). Kepemimpinan kepala sekolah yang efektif kunci pencapaian kualitas pendidikan. Jurnal Ilmu Pendidikan, 14(2).

Ifdil, I. (2010). Pendidikan Karakter dalam Bimbingan dan Konseling. Pedagogi: Jurnal Ilmu Pendidikan, $10(2), 55-61$.

Ifdil, I. (2013). Konsep Dasar Self Disclosure dan Pentingnya Bagi Mahasiswa Bimbingan dan Konseling. Pedagogi: Jurnal Ilmu Pendidikan, 13(1), 110-117.

Mahmood, Hussein ( 1993). Kepemimpinan dan Keberkesanan Sekolah. Kuala Lumpur : Majlis Bahasa dan Pustaka

Komariah, Aan, dkk. (2005). Visionary Leadership Menuju Sekolah Efektif.Jakarta : Bumi Aksara

Kusuma, I. H. (2004). Studi Kolerasional Antara Kecerdasan Adversity dan Motivasi Berprestasi dengan Kinerja Kepala Sekolah di Lingkungan Yayasan BPK Penabur Jakarta. Jurnal Pendidikan Penabur, (02), 17-34.

Manik, E., \& Bustomi, K. (2011). Pengaruh Kepemimpinan Kepala Sekolah, Budaya Organisasi Dan Motivasi Kerja Terhadap Kinerja Guru Pada SMP Negeri 3 Rancaekek. Jurnal Ekonomi, Bisnis \& Entrepreneurship, 5(2), 97-107.

Mukhtar \& Iskandar (2009) Oriantasi Baru Supervisi Pendidikan . Jakarta: Gaung Persada Press.

Mulyasa. (2011). Menjadi Kepala Sekolah Profesional. Bandung : PT. Remaja Rosdakarya.

Maduratna, M. (2013). Peranan Kepemimpinan Kepala Sekolah dalam Meningkatkan Efektivitas Kerja Guru dan Pegawai di Sekolah Dasar Negeri 015 Madura, 1(1), 70-84.

Nellitawati, N. (2012). Kontribusi Pengawasan Kepala Sekolah Terhadap Disiplin Kerja Guru SMA Negeri Di Kecamatan Koto Tangah Padang. Pedagogi: Jurnal Ilmu Pendidikan, 12(2), 24-31.

Parawansa, K. I. (2002). Hambatan terhadap Partisipasi Politik Perempuan di Indonesia. Perempuan Di Parlamen. Bukan Sekedar Jumlah, 41-52.

Rahman, A. (2010). Pendidikan (Dalam Rangka Pelaksanaan Manajemen Berbasis Sekolah ).

Sandra, R., \& Ifdil, I. (2015). Konsep Stres Kerja Guru Bimbingan dan Konseling. Jurnal EDUCATIO: Jurnal Pendidikan Indonesia, 1(1), 80-85.

Sudarsana, I. K. (2016). Pemikiran Tokoh Pendidikan Dalam Buku Lifelong Learning: Policies, Practices, And Programs (Perspektif Peningkatan Mutu Pendidikan di Indonesia). Jurnal Penjaminan Mutu, 2(2), 44-53.

Sutarto, M., Darmansyah, D., \& Warsono, S. (2014). Manajemen berbasis sekolah. The Manager Review Jurnal Ilmiah Manajemen, 13(3), 343-355.

Triyanto, E., Anitah, S., \& Suryani, N. (2013). Peran Kepemimpinan Kepala Sekolah dalam Pemanfaatan Media Pembelajaran Sebagai Upaya Peningkatan Kualitas Proses Pembelajaran. Teknologi Pendidikan, 1(2), 226-238.

Umaedi, U., Hadiyanto, H., \& Siswantari, S. (2014). Manajemen Berbasis Sekolah. [repository.ut.ac.id]. 
Wahjosumidjo (2005) Kepemimpinan Kepala Sekolah. Jakarta: PT Raja Grafindo Persada.

Widianti, D. (2016). Pengaruh Dimensi Strategi Inovasi Dan Pengungkapan Sustainability Report Terhadap Nilai Suatu Perusahaan Dengan Menggunakan Metode Tobin's Q (Studi kasus pada 9 Perusahaan Jakarta Islamic Indeks (JII) yang tercatat di Bursa Efek Indonesia Tahun 2009-2013).

Winarno, B. (2007). Sistem politik Indonesia era reformasi. Gramedia Pustaka Utama. 